TITLE:

\title{
The effects of magnesium deficiency on molybdenum metabolism in rats.
}

\section{$\operatorname{AUTHOR}(S)$ :}

Kim, Ki Hyun; Funaba, Masayuki; Yoshida, Munehiro; Matsui, Tohru

\section{CITATION:}

Kim, Ki Hyun ...[et al]. The effects of magnesium deficiency on molybdenum metabolism in rats.. Biological trace element research 2013, 151(1): 100-104

\section{ISSUE DATE:}

2013-01

URL:

http://hdl.handle.net/2433/168519

\section{RIGHT:}

The final publication is available at www.springerlink.com; This is not the published version. Please cite only the published version.; この論文 は出版社版でありません。引用の際には出版社版をご確認ご利用くだ さい。 


\title{
The effects of magnesium deficiency on molybdenum metabolism in rats
}

\author{
Ki Hyun Kim ${ }^{a}$, Masayuki Funaba ${ }^{a}$, Munehiro Yoshida $^{\mathrm{b}}$, Tohru Matsui ${ }^{\mathrm{a}}{ }^{*}$
}

${ }^{\mathrm{a}}$ Division of Applied Biosciences, Graduate School of Agriculture, Kyoto University, Kyoto, Japan

${ }^{\mathrm{b}}$ Faculty of Chemistry, Materials and Bioengineering, Kansai University, Osaka, Japan

Running title: Magnesium deficiency and molybdenum metabolism

* Corresponding Author: Tohru Matsui, PhD.

Division of Applied Biosciences

Kyoto University Graduate School of Agriculture

Kyoto 606-8502, Japan.

Tel: 81-75-753-6056

Fax: 81-75-753-6344

Email: matsui@kais.kyoto-u.ac.jp 


\begin{abstract}
Our previous report indicated that magnesium $(\mathrm{Mg})$ deficiency increased molybdenum (Mo) concentration in the rat liver, suggesting the possibility that Mg deficiency affects Mo metabolism. Growing male rats were given a control diet or an Mg-deficient diet for four weeks. Urine and feces were collected during the second and fourth weeks of the feeding trial. The liver, kidney, spleen, skeletal muscle, and blood were collected at the end of the feeding trial. $\mathrm{Mg}$ deficiency did not affect the apparent absorption of Mo, but it reduced urinary excretion of Mo. The retention of Mo tended to be higher in the Mg-deficient group than in the control group. Hepatic Mo concentration was higher in the Mg-deficient group than in the control group, but $\mathrm{Mg}$ deficiency did not affect Mo concentration in other tissues and plasma. Mg deficiency down-regulated the mRNA expression of Mo transporter 2 (MOT2) in the liver, but not in the kidney. These results suggest that Mg deficiency decreases urinary Mo excretion, which is too slight to affect plasma Mo concentration, and that $\mathrm{Mg}$ deficiency selectively disturbs the homeostatic mechanism of Mo in the liver, which is not related to the mRNA expression of MOT2 in the liver.
\end{abstract}

Key words: Magnesium deficiency; Molybdenum absorption; Molybdenum excretion; Molybdenum transporter; Liver 


\section{Introduction}

Molybdenum (Mo) is an essential trace element in animals; however, Mo deficiency is rare in animals and humans, and Mo toxicity is more likely than Mo deficiency [1]. Mo toxicity is associated with symptoms such as growth depression, reproductive failure, diarrhea, anemia, and gout-like symptoms in both humans and animals [2-5]. Further, Mo toxicity induces an inflammatory response in the liver $[6,7]$.

Dietary Mo is efficiently absorbed in animals [8,9] and humans [10]. The absorbed Mo is primarily excreted through urine; thus, urinary Mo excretion is considered to be the key pathway for maintaining Mo homeostasis [11]. Mo concentration was found to be relatively stable in many tissues, including the liver and kidney of rats, even if dietary Mo concentration was 4-fold higher than the nutritional requirement [12]. Another study reported that serum Mo concentration increased due to the dietary addition of Mo at a level 3-fold higher than the requirement in rats, but Mo concentration in the liver and kidney was not affected by this high level of dietary Mo [13]. Although urinary Mo excretion contributes to whole-body Mo homeostasis, another mechanism most likely plays a role in maintaining Mo homeostasis at the tissue level.

The sole known Mo transporter in animals was recently reported as the homologue of Mo transporter type 2 (MOT2) of the alga Chlamydomonas reinhardtii; heterologous expression in Saccharomyces cerevisiae of MoT2 gene from humans indicated that this protein transported Mo into cells [14].

Our previous study clarified that magnesium $(\mathrm{Mg})$ deficiency increased Mo concentration in the liver of rats [15]. We hypothesized that $\mathrm{Mg}$ deficiency disturbs the homeostatic mechanism of Mo and increases hepatic Mo concentration. In the present experiment, we investigated the effect of $\mathrm{Mg}$ deficiency on the apparent absorption and urinary excretion of Mo, Mo concentration in several tissues, and the expression of MOT2 mRNA of the rat homologue for human MOT2 in the liver and kidney.

\section{Materials and Methods}

Animals and diets

Twelve 4-week-old male Sprague-Dawley rats were purchased from SLC Japan (Shizuoka, Japan) and cared for according to the Guide for the Care and Use of Laboratory Animals (Animal Care Committee, Kyoto University). The rats were individually housed in metabolic cages fitted with urine and feces separators in a temperature-, humidity-, and light-controlled room $\left(24^{\circ} \mathrm{C}, 60 \%\right.$, and 12 -hour light/dark cycle, respectively).

All rats were given the control diet, which consisted of the AIN-93G diet [16], for a 6-day adaptation period. The rats were then allocated to two groups of six rats each and fed either the control diet or the low-Mg diet. The low-Mg diet was an AIN-93G-based diet with Mg-free AIN-93GMX [16]. The Mg concentration was measured at $513 \mathrm{mg} / \mathrm{kg}$ and $41 \mathrm{mg} / \mathrm{kg}$ for the control and low$\mathrm{Mg}$ diets, respectively. Rats given the control diet were pair-fed to match the intake of the rats given the low-Mg diet for four weeks. All rats were allowed free access to demineralized water during the feeding trial. One of the control rats was excluded from the experiment due to severe polyuria.

Sample collection

Urinary and fecal samples were collected from days 10 to 14 (the second week) and from days 24 to 28 (the fourth week) of the feeding trial for the determination of Mo balance.

Under isoflurane anesthesia, blood was obtained from the abdominal aorta with a heparinized syringe at the end of the feeding trial. Plasma samples were separated by centrifugation at $3,000 \times \mathrm{g}$ for $30 \mathrm{~min}$ at $4^{\circ} \mathrm{C}$. The liver, kidney, spleen, and skeletal muscle were excised promptly.

Portions of the hepatic and renal samples were washed with ice-cold isotonic saline, placed in 
RNA later liquid (AM7201, Applied Biosystems, USA) for 24 hours at $4{ }^{\circ} \mathrm{C}$, and then stored at $-80^{\circ} \mathrm{C}$ until mRNA analysis. The remaining liver and kidney tissues were stored at $-20^{\circ} \mathrm{C}$ until Mo analysis. The spleen, skeletal muscle, and plasma samples were also stored at $-20^{\circ} \mathrm{C}$ until Mo analysis.

Analytical methods

The urine, feces, tissue, and plasma samples were digested by a microwave high-pressure resolve device (ETHOS D, Milestone General, Japan) with trace-element-grade nitric acid (Wako Chemicals, Japan) and hydrogen peroxide (Wako Chemicals). The ${ }^{98}$ Mo concentration in the digested samples was determined by an inductively coupled plasma-mass spectrophotometer (ICP-MS, Elan 6000, Perkin Elmer, USA). Procedural accuracy of the Mo analysis was evaluated by spiking a rat liver sample with a respective standard solution; recovery for Mo was $101.8 \%$, and the coefficient of variation was $1.3 \%$. Mg concentration in digested plasma was determined by an atomic absorption spectrophotometer (AA-6600F, Shimadzu, Kyoto, Japan). Creatinine concentration in plasma and urine was determined by the Jaffé method [17].

Total RNA was extracted from hepatic and renal samples with TRIzol reagents (Invitrogen, USA) according to the manufacturer's protocol. The wavelength ratio at 260 and $280 \mathrm{~nm}$ was measured for quantitative analysis of the isolated RNA. Total RNA was reverse transcribed with random primers (ABI high-capacity cDNA reverse transcription kit, Applied Biosystems, USA). Aliquots of the cDNA were used as a template for the following quantitative PCR using a Real-Time PCR System (Rotor-Gene 6000, Corbett Research, Australia). The gene transcripts of MOT2 and $\beta$-actin were amplified using the SYBR Premix Ex Taq II (TaKaRa Bio, Japan) as described previously [18].

The gene product of MFSD5 (major facilitator superfamily domain containing 5) was identified as MOT2 in humans (GenBank accession no. BAC11137) [14]. Although the activity of MOT2 as an Mo transporter is not determined in rats, the rat homologue of human MFSD 5 has been recorded (GenBank accession no. NM_001126282). The following PCR primer set was used: forward, 5'TGACTTCCCTGCCGAGTG-3' and reverse, 5'-CCAGCACATGGTTCCAGA-3' for the rat MOT2 (NM_001126282); and forward, 5'-ACCCGCGAGTACAACCTTCT-3' and reverse, 5'TCGTCATCCATGGCGAACTG-3' for the rat $\beta$-actin (GenBank accession number: NM_031144.2). The relative levels of MOT2 mRNA expression were normalized against the mRNA level of $\beta$-actin and represented as a ratio of the MOT2 mRNA level in the control group for each tissue type.

Calculation and Statistical analysis

Apparent absorption and retention of Mo were calculated in the second and fourth weeks of the feeding trial as follows:

Apparent absorption of Mo $(\mu \mathrm{g} /$ day $)=$ Mo intake $(\mu \mathrm{g} /$ day $)$ - Fecal Mo excretion $(\mu \mathrm{g} /$ day $)$; Retention of Mo $(\mu \mathrm{g} /$ day $)=$ Apparent absorption of Mo $(\mu \mathrm{g} /$ day $)-$ Urinary Mo excretion $(\mu \mathrm{g} /$ day $)$.

The glomerular filtration rate (GFR) was approximated by creatinine clearance [19]. The GFR, Mo filtration at the glomerulus, and Mo reabsorption were calculated in the fourth week as follows:

GFR $(\mathrm{mL} /$ day $)=[$ Urinary creatinine excretion $(\mathrm{mg} /$ day $)] /$ Plasma creatinine concentration $(\mathrm{mg} / \mathrm{mL})$; Mo filtration $(\mu \mathrm{g} /$ day $)=$ GFR $(\mathrm{mL} /$ day $) \times$ Plasma Mo concentration $(\mu \mathrm{g} / \mathrm{mL})$; Mo reabsorption $(\mu \mathrm{g} /$ day $)=$ Mo filtration $(\mu \mathrm{g} /$ day $)$ - Urinary Mo excretion $(\mu \mathrm{g} /$ day $)$; Fractional reabsorption of Mo $(\%)=[$ Mo reabsorption $(\mu \mathrm{g} /$ day $) /$ Mo filtration $(\mu \mathrm{g} /$ day $)] \times 100$.

Data were expressed as the mean and standard error of the mean (SEM). The Mo balance data were analyzed with a repeated ANOVA with the statistical model consisting of the effect of treatment (Mg deficiency and control), the effect of period (the second week and the fourth week) and their interaction. All remaining data were analyzed using a one-way ANOVA. The statistical analyses were performed with SPSS 17.0 software (SPSS Inc., Chicago, IL, USA).

\section{Results}


Symptom of magnesium deficiency

Plasma Mg concentration was 23.0 and 8.8 (SEM, 2.3) $\mathrm{mg} / \mathrm{L}$ in the control diet and low-Mg diet groups, respectively, and a significant effect of the dietary treatment was observed $(\mathrm{P}<0.001)$.

Beginning 3 days after the initiation of dietary treatment, all of the rats fed the low-Mg diet presented with skin lesions on the ears and tail, a typical sign of $\mathrm{Mg}$ deficiency. However, no skin lesions were observed in rats given the control diet during the feeding trial (data not shown). These results indicate that the rats given the low-Mg diet suffered from $\mathrm{Mg}$ deficiency in the present experiment.

Molybdenum concentration in the tissues and plasma

The Mg-deficient group had a higher $(\mathrm{P}=0.033)$ hepatic Mo concentration than the control group (Table 1). On the other hand, the dietary treatment did not affect Mo concentration in the other tissues. The plasma Mo concentrations were similar in both groups.

\section{Molybdenum balance}

We determined Mo balance in the second and the fourth weeks of the feeding trial (Table 2). Dietary treatment did not affect Mo intake because the animals were pair-fed. The duration of the experiment significantly affected Mo intake $(\mathrm{P}=0.019)$. The apparent absorption of Mo was not affected by the treatment, and a significant interaction was not observed. Thus, Mg deficiency did not affect the apparent absorption of Mo during each period. Urinary excretion of Mo was affected by the treatment $(\mathrm{P}=0.005)$, but a significant interaction was not observed. These results indicate that $\mathrm{Mg}$ deficiency decreased urinary Mo excretion, irrespective of the collection period. The retention of Mo tended to increase as a result of treatment $(\mathrm{P}=0.077)$, but no significant interaction was noted.

\section{Renal handling of molybdenum}

Plasma creatinine concentration was 4.26 and 4.50 (SEM 0.15) $\mathrm{mg} / \mathrm{L}$ in the control and $\mathrm{Mg}$ deficient groups, respectively, and the effect of treatment was not significant. GFR was significantly lower $(\mathrm{P}=0.002)$ in the $\mathrm{Mg}$-deficient group than in the control group (Table 3). The Mo filtration at the glomerulus was also lower $(\mathrm{P}=0.021)$ in the $\mathrm{Mg}$-deficient group than in the control group. The fractional reabsorption of Mo was not affected by the dietary treatment; thus, the amount of Mo reabsorption was significantly lower $(\mathrm{P}=0.023)$ in the $\mathrm{Mg}$-deficient group than in the control group because Mo filtration was lower for the $\mathrm{Mg}$-deficient group. As a result, $\mathrm{Mg}$ deficiency decreased urinary Mo excretion by decreasing GFR without increasing the efficiency of Mo reabsorption.

\section{Expression of MOT2 mRNA}

We determined the expression of MOT2 mRNA in the liver and kidney. Mg deficiency downregulated mRNA expression of MOT2 in the liver $(\mathrm{P}=0.036)$ but did not affect its expression in the kidney (Fig. 1).

\section{Discussion}

The present experiment clarifies that: 1) Mg deficiency decreased urinary Mo excretion by decreasing GFR, and the reduction of urinary Mo excretion slightly affected Mo retention (Table 2, 3); 2) $\mathrm{Mg}$ deficiency increased Mo concentration in the liver but not in other tissues and plasma (Table 1); and 3) Mg deficiency down-regulated mRNA expression of MOT2 (Fig. 1), which is the only known Mo transporter in animals and is responsible for cellular Mo uptake [14]. These results suggest that $\mathrm{Mg}$ deficiency selectively increases hepatic Mo concentration by an unknown mechanism.

$\mathrm{Mg}$ deficiency has been reported to affect other mineral concentrations in various tissues and plasma [20-23]. Our previous study indicated that Mg deficiency increased hepatic Mo concentration 
in rats [15], which was confirmed by the present experiment (Table 1). Therefore, we hypothesized that $\mathrm{Mg}$ deficiency disturbs the homeostatic mechanism of Mo.

We investigated the effect of Mg deficiency on Mo balance and renal handling of Mo. The duration of the experiment significantly increased Mo intake because feed intake increased with growth in the Mg-deficient group (Table 2). Mg deficiency did not affect the apparent absorption of Mo (Table 2). However, Mg deficiency decreased GFR (Table 3), which was supported by a report using inulin clearance for assessing GFR in rats [24], resulting in the reduction of urinary Mo excretion in the present study (Table 2). Because urinary Mo excretion is considered to be the key pathway for maintaining Mo homeostasis [11], Mo retention is probably affected by urinary Mo excretion. We consider that the decrease in urinary excretion of Mo increased Mo retention in $\mathrm{Mg}$ deficient rats, although the effect of dietary treatment on Mo retention was not significant in the present study. Mo is efficiently absorbed, and plasma or serum Mo concentration readily increases with an elevated Mo intake in humans [25] and in rats [13]. It must be noted that Mg deficiency did not affect plasma Mo concentration, which suggests that the increase in Mo retention is too slight to increase plasma Mo concentration.

Mg deficiency increased hepatic Mo concentration but did not affect Mo concentration in the other tissues (Table 1). These results indicate that $\mathrm{Mg}$ deficiency selectively increases hepatic Mo concentration. Jimenez et al. [14] identified an Mo transporter in humans, MOT2, which is also the sole Mo transporter discovered in animals. MOT2 transports Mo into cells and MOT2 mRNA is expressed in a number of tissues, including the liver. The present experiment showed that the expression of MOT2 mRNA was down-regulated, not up-regulated, by Mg deficiency in the liver (Fig. 1). Therefore, the increase in hepatic Mo concentration is unlikely to result from the increase in Mo uptake by up-regulating MOT2 expression. The expression of MOT2 is transcriptionally up-regulated after Mo shortage in the alga [14]. We can speculate that the expression of MOT2 mRNA is also regulated by Mo status in the liver; the increase in hepatic Mo concentration suppresses MOT2 mRNA expression, which plays a role in maintaining Mo homeostasis in the liver.

In conclusion, $\mathrm{Mg}$ deficiency selectively disturbs the homeostatic mechanism of Mo in the liver. Further studies are necessary for clarifying how Mg deficiency increases hepatic Mo concentration.

\section{Conflict of interest}

The authors declare that they have no conflict of interest.

\section{Acknowledgements}

The authors thank Emeritus Professor Yoshinori Itokawa and former Associate Professor Mieko Kimura of the Division of Social and Preventive Medicine, Graduate School of Medicine, Kyoto University, for giving us a chance to use ICP-MS. 


\section{References}

1. Rajagopalan KV (1988) Molybdenum: an essential trace element in human nutrition. Annu Rev Nutr 8:401-427

2. Jeter MA, Davis GK (1954) The effect of dietary molybdenum upon growth, hemoglobin, reproduction, and lactation of rats. J Nutr 54:215-220

3. Cox DH, Davis GK, Shirley RL, Jack FH (1960) Influence of excess dietary molybdenum on rat and calf liver and heart enzymes. J Nutr 70:63-68

4. Ostrom CA, Reen RV, Miller CW (1961) Changes in the connective tissue of rats fed toxic diets containing molybdenum salts. J Dent Res 40:520-528

5. Walravens PA, Moureeraso R, Solomons CC, Chapell WR, Bentley G (1979) Biochemical abnormalities in workers exposed to molybdenum dust. Arch Environ Health 34:302-308

6. Bandyopadhyay SK, Chatterjee K, Tiwari RK, Mitra A, Banerjee A, Ghosh KK, Chatterjee GC (1981) Biochemical studies on molybdenum toxicity in rats: effects of high protein feeding. Int J Vitam Nutr Res 51:401-409

7. Johnson HL, Miller RF (1963) Possible mechanisms for dietary molybdenum toxicity in the rat. J Nutr 81:271-278

8. Bibr B, Lener J (1973) Excretion of molybdenum by experimental animals. Physiol Bohemoslov 22:167-178

9. Neilands JB, Strong FM, Elvehjem CA (1948) Molybdenum in the nutrition of the rat. J Biol Chem 172:431-439

10. Novotny JA, Turnlund JR (2007) Molybdenum intake influences molybdenum kinetics in men. J Nutr 137:37-42

11. Turnlund, JR, Keyes WR, Peiffer GL, Chiang G (1995) Molybdenum absorption, excretion, and retention studied with stable isotopes in young men at five intakes of dietary molybdenum. Am $\mathbf{J}$ Clin Nutr 62:790-796

12. Wang X, Oberleas D, Yang MT, Yang SP (1992) Molybdenum requirement of female rats. J Nutr 122:1036-1041

13. Yoshihara K, Fukunaga K, Yoshida M (2007) Effect of dietary molybdenum level on tissue and serum molybdenum concentrations in rats. Trace Nutrients Res 24:120-123

14. Tejada-Jiménez M, Galván A, Fernández E (2011) Algae and humans share a molybdate transporter. Proc Natl Acad Sci USA 108:6420-6425

15. Kim KH, Ishizaki N, Iguchi E, Funaba M, Matsui T (2011) Effect of magnesium deficiency on various mineral concentrations in rat liver. Biol Trace Elem Res 144:865-871

16. Reeves PG (1997) Components of the AIN-93 diets as improvements in the AIN-76A diet. J Nutr 127:838S-841S

17. Bonsnes RW, Taussky HH (1945) On the colorimetric determination of creatinine by the jaffé reaction. J Biol Chem 158:581-591

18. Ishizaki N, Kotani M, Funaba M, Matsui T (2011) Hepcidin expression in the liver of rats fed a magnesium-deficient diet. Br J Nutr 106:1169-1172

19. Smetana S, Khalef S, Nitsan Z, Hurwitz N, Miskin A, Bar-Khayim Y, Birk Y (1988) Enhanced urinary trypsin inhibitory activity in gentamicin-induced nephrotoxicity in rats. Clin Chim Acta 176:333-342

20. Kimura M, Itokawa Y (1989) Inefficient utilization of iron and minerals in magnesium deficient rats. In: Itokawa Y, Durlach J (ed) Magnesium in Health and Disease. John Libbey, London, pp 95-102

21. Sanchez-Morito N, Planells E, Aranda P, Llopis J (2000) Influence of magnesium deficiency on the bioavailability and tissue distribution of iron in the rat. J Nutr Biochem 11:103-108

22. Vormann J, Günther T, Höllriegl V, Schümann K (1995) Effect of various degrees and duration of magnesium deficiency on lipid peroxidation and mineral metabolism in rats. J Nutr Biochem 
6:681-688

23. Jimenez A, Planells E, Aranda P, Sanchez-Vinas M, Llopis J (1997) Changes in bioavailability and tissue distribution of copper caused by magnesium deficiency in rats. J Agric Food Chem 45:4023-4037

24. Ginn HE, Shanbour LL (1966) Phosphaturia in magnesium-deficient rats. Am J Physiol 212:1347-1350

25. Turnlund JR, Keyes WR (2004) Plasma molybdenum reflects dietary molybdenum intake. J Nutr Biochem 15:90-95 
Table 1. Effect of Mg deficiency on Mo concentrations in several tissues and plasma of rats

\begin{tabular}{lcccc}
\hline & Control & Mg deficiency & SEM $^{\mathrm{a}}$ & P value \\
\hline Liver, $\mu \mathrm{g} / \mathrm{kg}$ & 434 & 531 & 24 & 0.033 \\
Kidney, $\mu \mathrm{g} / \mathrm{kg}$ & 291 & 282 & 7 & 0.546 \\
Spleen, $\mu \mathrm{g} / \mathrm{kg}$ & 84 & 98 & 5 & 0.167 \\
Skeletal muscle, $\mu \mathrm{g} / \mathrm{kg}$ & 18 & 27 & 3 & 0.114 \\
Plasma, $\mu \mathrm{g} / \mathrm{L}$ & 30 & 29 & 2 & 0.956 \\
\hline
\end{tabular}

Values are means.

a'SEM: Standard error of mean (Control: $n=5$; Mg deficiency: $n=6$ ) 
Table 2. Effect of Mg deficiency on Mo balance in rats

\begin{tabular}{|c|c|c|c|c|c|c|c|c|}
\hline & \multicolumn{2}{|c|}{ 2nd week } & \multicolumn{2}{|c|}{4 th week } & \multirow{2}{*}{ SEM $^{\mathrm{a}}$} & \multicolumn{3}{|c|}{$P$ value } \\
\hline & Control & $\begin{array}{c}\mathrm{Mg} \\
\text { deficiency }\end{array}$ & Control & $\begin{array}{c}\mathrm{Mg} \\
\text { deficiency }\end{array}$ & & Treat $^{\mathrm{b}}$ & Time $^{c}$ & $\operatorname{Int}^{\mathrm{d}}$ \\
\hline \multicolumn{9}{|c|}{$\mu \mathrm{g} / \mathrm{day}$} \\
\hline Intake & 2.76 & 2.85 & 2.96 & 2.96 & 0.03 & 0.514 & 0.019 & 0.431 \\
\hline Apparent absorption & 2.17 & 2.01 & 2.51 & 2.42 & 0.06 & 0.211 & 0.003 & 0.726 \\
\hline Urinary excretion & 2.36 & 1.75 & 2.77 & 2.43 & 0.11 & 0.005 & 0.018 & 0.497 \\
\hline Retention & -0.19 & 0.26 & -0.26 & -0.01 & 0.09 & 0.077 & 0.361 & 0.590 \\
\hline
\end{tabular}

Values are means.

${ }^{a}$ SEM: Standard error of mean (Control: $n=5 ;$ Mg deficiency: $n=6$ )

${ }^{\mathrm{b}}$ Treat, Effect of treatment; ${ }^{\mathrm{c}}$ Time, Effect of sampling period; ${ }^{\mathrm{d}}$ Int, Interaction between treatment and period 
Table 3. Effect of Mg deficiency on renal handling of Mo in rats

\begin{tabular}{lcccc}
\hline & Control & Mg deficiency & SEM $^{\mathrm{a}}$ & P value \\
\hline GFR $^{\mathrm{b}}, \mathrm{mL} /$ day & 1,574 & 1,148 & 81 & 0.002 \\
Mo filtration, $\mu \mathrm{g} /$ day & 46.6 & 32.8 & 3.2 & 0.021 \\
Mo reabsorption, $\mu \mathrm{g} /$ day & 43.8 & 30.4 & 3.1 & 0.023 \\
Fractional reabsorption of Mo, $\%$ & 93.8 & 92.5 & 0.5 & 0.238 \\
\hline
\end{tabular}

Values are means.

${ }^{a}$ SEM, Standard error of mean (Control, $\mathrm{n}=5 ; \mathrm{Mg}$ deficiency, $\mathrm{n}=6$ )

${ }^{\mathrm{b}} \mathrm{GFR}$, Glomerular filtration rate estimated by creatinine clearance. 


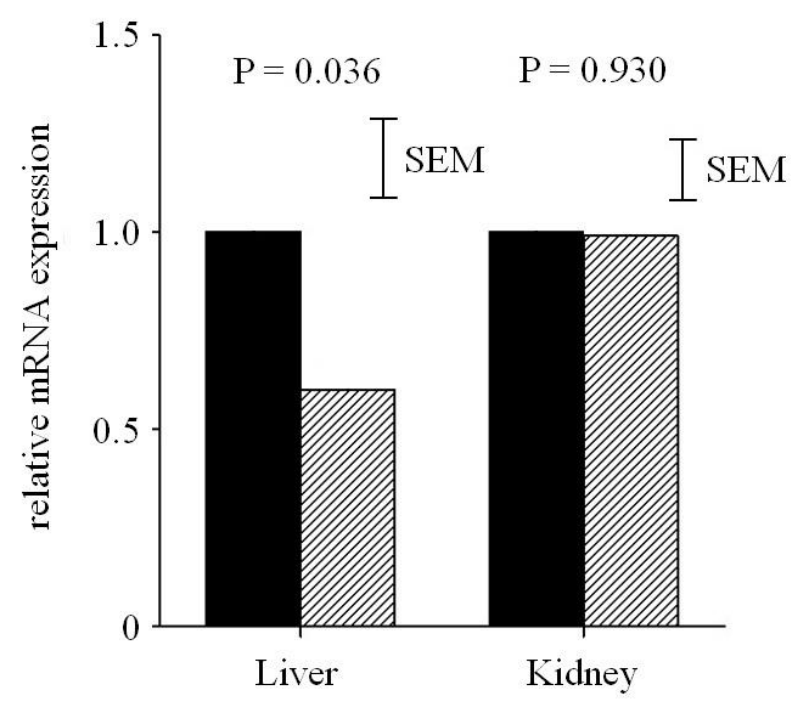

Figure 1. Effect of Mg deficiency on MOT2 mRNA expression in the liver and kidney. Data are expressed as a value relative to the control group, and error bars indicate the SEM. Closed and hatched columns indicate results for the control $(n=5)$ and Mg-deficient groups $(n=6)$, respectively. 